\title{
Australian Journal of \\ Crop Science \\ Individual and population behavior of soybean plants grown in rows with different proportions of high- and low-vigor seeds
}

\author{
Mateus Pino, Luis Osmar Braga Schuch, César Iván Suárez Castellanos, Felipe Koch", Vinícius Jardel \\ Szareski, João Roberto Pimentel, Cristian Troyjack, Ivan Ricardo Carvalho, Andrea Bicca Noguez Martins, \\ Francielen Lima da Silva, Márcio Peter, Manoela Andrade Monteiro, Gustavo Henrique Demari, Tiago \\ Zanatta Aumonde, Tiago Pedó
}

\author{
Universidade Federal de Pelotas, Faculdade de Agronomia Eliseu Maciel, Departamento de Fitotecnia, Capão do \\ Leão, Rio Grande do Sul, Brazil
}

\section{*Corresponding author: felipe.koch@hotmail.com}

\begin{abstract}
The objective of the present work was to evaluate the influence of high- and low-vigor soybean seeds on the agronomic characteristics, yield components and seed yield of individual plants and plant communities grown in rows containing different proportions of high- and low-vigor seedlings. The experiment was conducted in the county of Selbach-RS, Brazil, in the 2012/2013 crop year using the short-cycle soybean cultivar FPS Urano RR. The experimental design was completely randomized, with five replications. Seven different proportions of high and low seedling vigor distribution along the growing line were selected: T1 (100\% HV); T2 (83.3\% HV and 16.7\% LV); T3 (66.6\% HV and 33.3\% LV); T4 (50\% HV and 50\% LV); T5 (33.3\% HV and 66.6\% LV); T6 (16.7\% HV and $83.3 \% \mathrm{LV})$; and T7 (100\% LV), where HV and LV indicate high and low vigor, respectively. Based on the results obtained, it was found that: plants originating from high-vigor seeds were taller than low-vigor plants at the V5 and R8 phenological stages; even when populations originated only from seeds with low vigor, yield levels did not reach those found for high-vigor seeds; values of thousand seed weight and number of pods per plant with one seed did not differ between high- and low-vigor seeds, individually; the yield components number of seeds and seeds per plant contributed most to increase yield for the vigor proportions studied; and populations formed only of seeds with high vigor exhibited a seed yield per area $21 \%\left(928 \mathrm{~kg} \mathrm{ha}^{-1}\right)$ greater than that formed only by low-vigor seeds.
\end{abstract}

Keywords: Glycine max (L.) Merrill; physiological quality; seed yield; yield components.

Introduction

Brazil is one of the world's leading producers of soybeans, with current production approaching approximately 118 million tons (Conab, 2018). This figure is a reflection of advances in research and new technologies applied to production, highlighting the current cultivars' yield potential, which may or may not be expressed by the physiological quality of their seeds. Peske et al. (2012) have argued that seed improvement allows farmers to exploit the full potential of cultivars through increases in genetic, physical and physiological quality.

According to Popinigis (1977), physiological quality is defined as the ability to perform vital functions, as characterized by germination, vigor and longevity that directly affect the implantation of the culture in the field. For Marcos Filho (2002), high-quality seeds possess several attributes of which physiological parameters are most significant, particularly germination and vigor. Based on this, the manifestation of low physiological potential in batches of seeds includes a low germination rate, higher sensibility of seeds and seedlings to stress during this process, as well as plants exhibiting slow growing, reduced, uneven and smaller root development (Marcos Filho, 2015; Szareski et al., 2018a). This lower emergence rate is due to the fact that low-vigor seeds, before initiating the growth of the embryonic axis, require more time for the restoration of organelles and damaged tissues (Villiers, 1973).

When batches of low-vigor seeds are used, yield normally goes down due to the uneven establishment of plants and population to below that recommended for the cultivar, thus impairing production. As a result, low-vigor seeds are associated with decreased and uneven emergence, decreased initial height in seedlings, as well as reduction in dry matter production, leaf area, use of reserves and culture growth rate (Khah et al., 1989; Schuch, 1999; Schuch et al., 2000; Machado, 2002; Hofs, 2003; Schuch et al., 2009; Henning et al., 2010; Scheeren et al., 2010; Mielezrski and 
Marcos Filho, 2012; Zimmer et al., 2016; Zanatta et al., 2018; Vargas et al., 2018). This in turn affects the establishment of the culture, potentially influencing its performance during the growth cycle and hence also its final yield. According to Carvalho and Toledo (1978), low-vigor seeds have reduced capability and conditions with which to restore their damaged tissues, with the emergence of these seedlings occurring later than those of high vigor. Similarly, Khah et al. (1989) observed that rapid emergence, associated with faster seedling growth arising from high quality seeds, provided better yields than those of plants originating from low-vigor seeds.

Tekrony and Egli (1991) stated that the physiological potential of seeds can not only have an indirect influence on field yield by affecting the speed of emergence and emergence rate of seedlings and initial stands, but can also directly impact grain yield through its influence on plant vigor. In Kolchinski et al.'s (2005) study of plant communities comprising different levels of seed quality combinations, the authors observed that plants arising from high quality seeds have a better grain yield. These results thus indicate that the use of more vigorous seeds provides larger seedlings and greater initial growth, and may also affect the development of the culture throughout its cycle (Marcos Filho, 2015; Szareski et al., 2018).

Scheeren (2002) noted that soybean plants grown from high physiologic quality seeds exhibited greater height 21 days after sowing than those grown from low quality seeds, with this initial advantage sufficient to result in a better grain yield. Similar results were found by Kolchinski (2003), who reported that the use of high-vigor seeds in the establishment of soybean plant communities provided an increase of more than $35 \%$ in seed yield, in relation to the use of low-vigor seeds. Elsewhere, Melo et al. (2006) and Mielezrscki et al. (2008) observed that rice plants arising from high-vigor seeds had a higher yield than those arising from low-vigor seeds.

Considering the above, the present work aimed to evaluate the effects of high- and low-vigor seedlings, distributed in varying proportions along a crop row of one meter in length, on the yield components and yield of seeds per area, both individually and in terms of the overall performance of the communities formed.

\section{Results and discussion}

\section{Morphological and seed yield characteristics in individual plants}

High-vigor plants had a greater average height in all treatments when compared with plants of low vigor from the same population, at the V5 phenologic stage (Fig. 1-a). This result was repeated, at $R 8$, in treatments up to those comprising $50 \%$ plants of each vigor quality, after which, i.e. with a decrease in high-vigor plants in the population, the average plant height was equal between the two vigor levels studied (Fig. 1-b). It should also be noted that whereas an increase in low-vigor plants in the population at $\mathrm{V} 5$ resulted in a decrease in the average height of plants, the same pattern was not observed for high-vigor plants at R8, a difference in height potentially reflecting a higher seed yield (Scheeren et al., 2010; Gabriel et al., 2018). In oats, Machado (2002) evaluated the behavior of plants until 30 days after emergence, finding that plants arising from seeds of high physiological quality were taller than low quality plants throughout the study period. This suggests that, despite their better growth capability, the high-vigor plants increased in height only until reaching the point that they could outstrip the surrounding plants, or at least until reaching the same height as the low-vigor plants, thereby having an advantage in terms of solar radiation intake. In the present study, a comparison of high-vigor plants in treatments T1 $(100 \% \mathrm{HV})$ and T6 $(16.7 \% \mathrm{HV})$ reveals a significant decrease in average plant height. Vanzolini and Carvalho (2002) observed that batches of low physiological quality soybean seeds produced smaller plants at 18 and 38 days after sowing, compared with medium and high quality batches. According to the authors, their results reflect the speed of emergence of seedlings originating from low quality seeds, which was significantly lower than that of the other batches tested. According to Edje and Burris (1971), soybean seeds of low vigor emerge slowly and produce plants of a smaller initial size.

Analysis of stalk diameter and number of ramifications (Fig. 1-c and Fig. 1-d) revealed significant differences. Comparing high- and low-vigor plants both within and between treatments, high-vigor plants exhibited a larger stalk diameter, as well as a higher number of ramifications for all HV:LV ratios. Similar results were reported in the study conducted by Tavares et al. (2013), where high-vigor seeds produced soybean plants with greater height and stalk diameter, under periods of hydric stress during vegetative stages. Kolchinski et al. (2006) observed that soybean plants arising from seeds of greater vigor presented higher culture growth rates, as well as greater plant dry matter and leaf area at 30 days after emergence, in comparison to plants with lower vigor.

When comparing plants within the same treatment, it is apparent that those of higher vigor produced more seeds per plant (Fig. 2-d) than those of low vigor. This result is largely due to the number of pods with two seeds, which rose with an increase in high-vigor plants in the crop row. The same relationship between the proportion of high-vigor plants and number of seeds per plant was also observed for pods containing one or three seeds per plant, although a lower number of these two types of pod were produced (Fig. 2-a and Fig. 2-c). However, the difference in the number of pods with one or three seeds was not significant between the $100 \% \mathrm{HV}$ and $100 \%$ LV treatments.

The number of seeds and pods per plant may also be related to the higher content of soluble proteins, starch and sugars in more vigorous seeds (Henning et al., 2010; Szareski et al., 2018b), which may produce taller plants and possibly a higher number of reproductive nodes per plant.

Similar results were found by Popinigis (1973), where soybean seeds of high physiological quality produced plants with a greater number of racemes and pods, resulting in a greater seed yield. Likewise, Kolchinski et al. (2005) reported that a higher seed yield was observed in plants grown from 

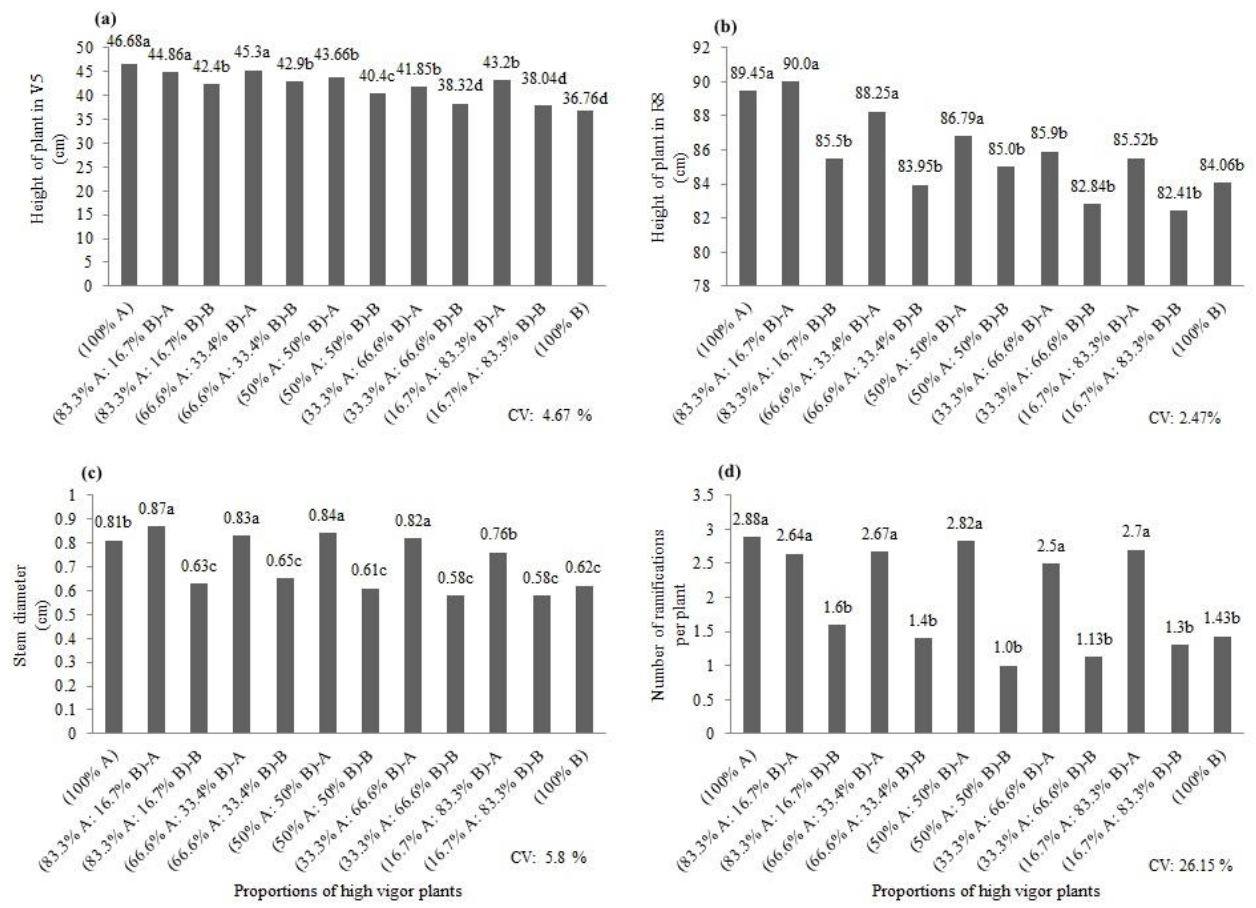

Fig 1. Individual height of soybean plants at the V5 (a) and R8 (b) phenological stages, stalk diameter (c) and number of ramifications per plant (d), in treatments consisting of different proportions of soybean plants with high and low vigor. Selbach-RS. A: high-vigor plants; B: low-vigor plants. T: treatment. T1 (100\% A); T2 (83.3\% A: 16.7\% B)-A; T3 (66.6\% A: 33.3\% B)-A; T4 (50\% A: 50\% B)-A; T5 (33.3\% A: 66.6\% B)-A; T6 (16.7\% A: 83.3\% B)-A: high-vigor plants. T2 (83.3\% A: 16.7\% B)-B; T3 (66.6\% A: 33.3\% B)-B; T4 (50\% A: 50\% B)-B; T5 (33.3\% A: 66.6\% B)-B; T6 (16.7\% A: 83.3\% B)-B; T7 (100\% B): low-vigor plants. ${ }^{1}$ Averages followed by the same letter do not differ according to the Scott-Knott test at the $5 \%$ significance level. $C V$ : coefficient of variation.
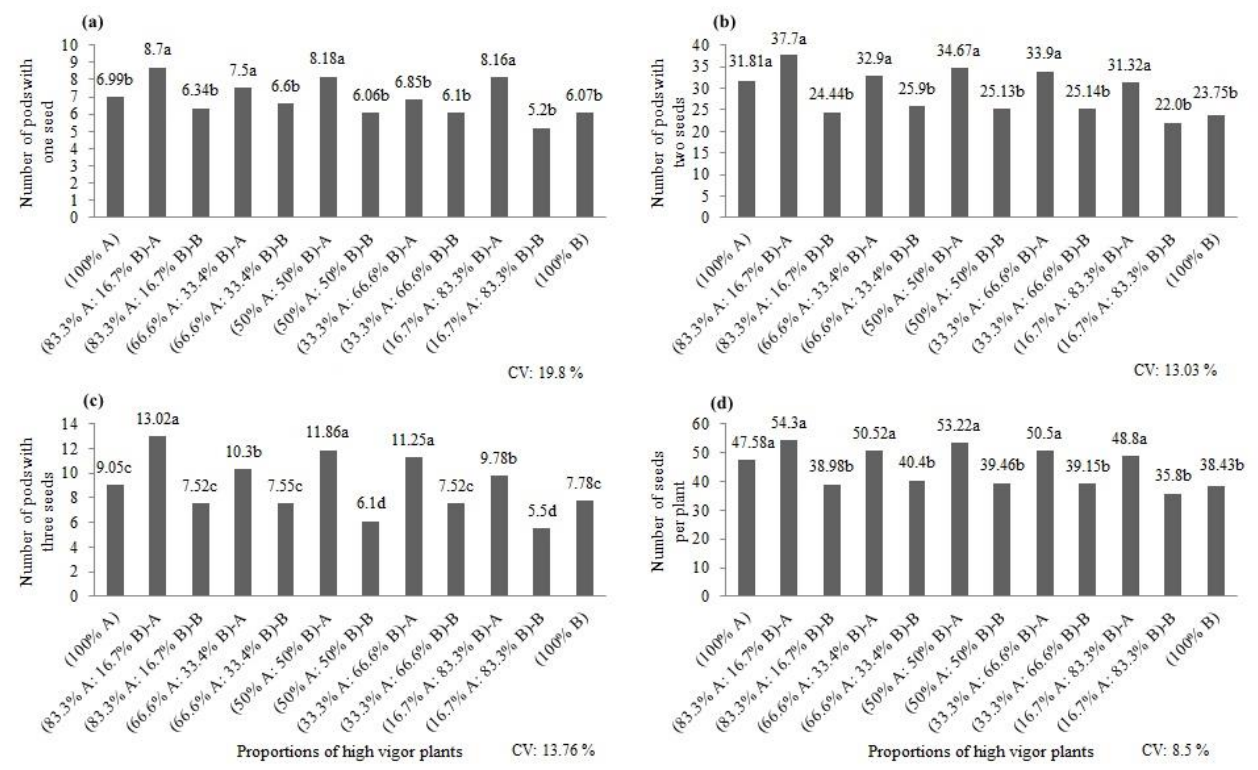

Fig 2. Number of pods with one seed (a), number of pods with two seeds (b), number of pods with three seeds (c), and total number of seeds per plant (d) in treatments consisting of different proportions of soybean plants of high and low vigor. Selbach-RS. A: high-vigor plants; B: low-vigor plants. T: treatment. T1 (100\% A); T2 (83.3\% A: 16.7\% B)-A; T3 (66.6\% A: 33.3\% B)-A; T4 (50\% A: 50\% B)-A; T5 (33.3\% A: 66.6\% B)-A; T6 (16.7\% A: 83.3\% B)-A: high-vigor plants. T2 (83.3\% A: 16.7\% B)-B; T3 (66.6\% A: 33.3\% B)-B; T4 (50\% A: 50\% B)-B; T5 (33.3\% A: 66.6\% B)-B; T6 (16.7\% A: 83.3\% B)-B; T7 (100\% B): low-vigor plants. ${ }^{1}$ Averages followed by the same letter do not differ according to the Scott-Knott test at the $5 \%$ significance level. CV: coefficient of variation. 

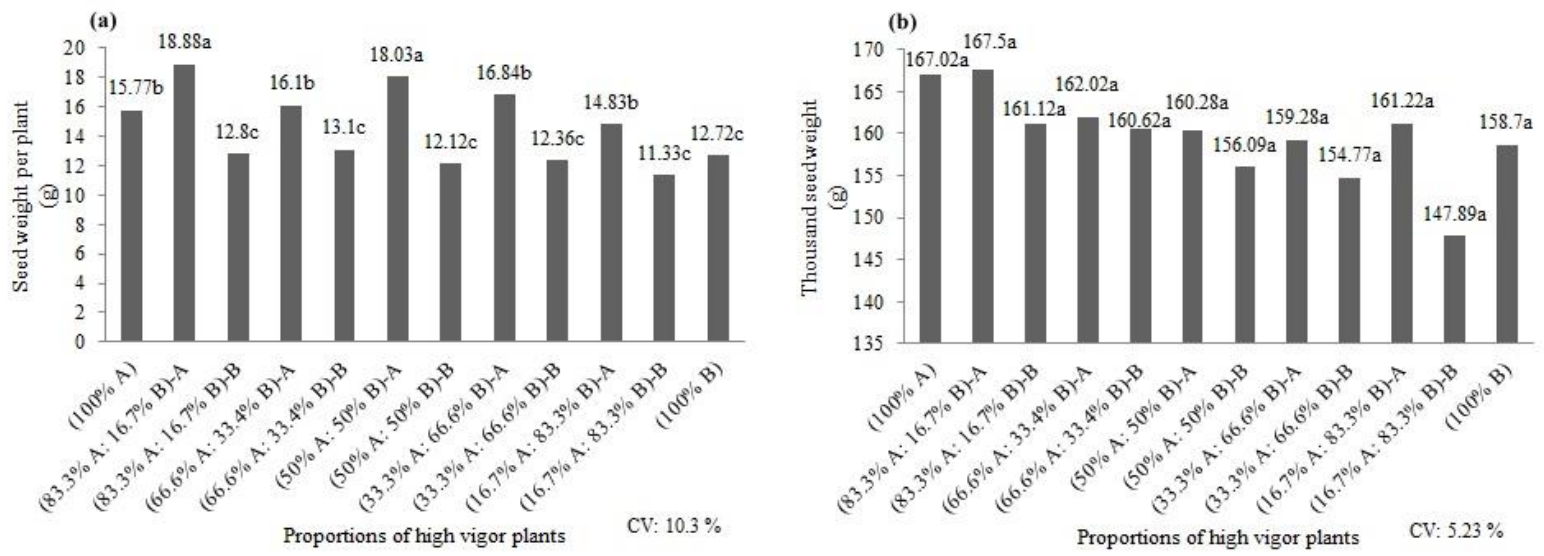

Fig 3. Weight of seeds per plant (a) and thousand seed weight (b) in treatments consisting of different proportions of soybean plants with high and low vigor. Selbach-RS. A: high-vigor plants; B: low-vigor plants. T: treatment. T1 (100\% A); T2 (83.3\% A: $16.7 \%$ B)-A; T3 (66.6\% A: 33.3\% B)-A; T4 (50\% A: 50\% B)-A; T5 (33.3\% A: 66.6\% B)-A; T6 (16.7\% A: 83.3\% B)-A: high-vigor plants. T2 (83.3\% A: $16.7 \%$ B)-B; T3 (66.6\% A: 33.3\% B)-B; T4 (50\% A: 50\% B)-B; T5 (33.3\% A: 66.6\% B)-B; T6 (16.7\% A: 83.3\% B)-B; T7 (100\% B): lowvigor plants. ${ }^{1}$ Averages followed by the same letter do not differ according to the Scott-Knott test at the $5 \%$ significance level. CV: coefficient of variation.
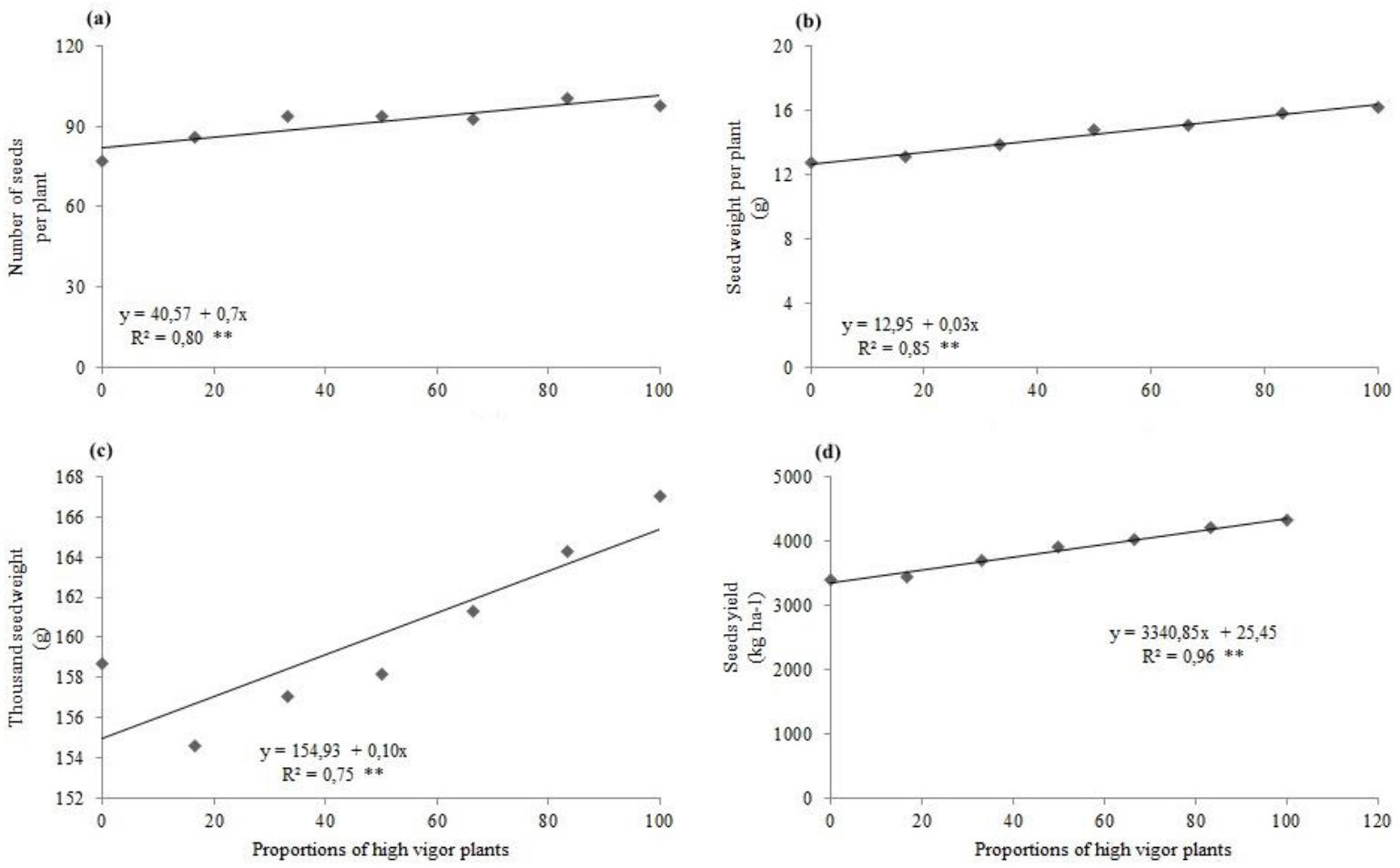

Fig 4. Variation in number of seeds per plant (a), weight of seeds per plant (b), thousand seed weight (c) and seed yield per area (kg $\left.\mathrm{ha}^{-1}\right)(\mathrm{d})$ with an increasing proportion of high-vigor plants in the treatment population. 
seeds of high vigor, mainly due to the number of pods per plant.

Because of the higher number of seeds, seed weight per plant (Fig. 3-a) also increased with an increasing proportion of high vigor plants in the crop row. In all treatments, seed weight in plants of high vigor was significantly higher than that in low-vigor plants. A small decrease in thousand seed weight (Fig. 3-b) was also observed with an increase in the proportion of low-vigor plants, although values were not statistically significantly different between low- and highvigor plants in the same treatment, and between low-vigor plants in different treatments.

The larger mass of one thousand seeds recorded here for the plants obtained using high-vigor seeds may be related to the greater accumulation of reserves in these seeds (Henning et al., 2010; Szareski et al., 2018), a result previously observed in maize plants (Mondo et al., 2012).

Similar behavior was reported by Schuch et al. (2009) in isolated soybean plants, with no difference in thousand seed weight recorded between high- and low-vigor plants. This finding allowed the latter authors to confirm that the number of seeds per plant was the yield component that most influenced seed weight per plant. In an earlier study, Pinthus and Kimel (1979) observed that differences in plant yield according to the level of seed vigor were caused by variations in the number of pods per plant, and thus also in seed weight per plant.

In the present study, high-vigor plants generally exhibited a number of advantages over low-vigor plants, when compared both within and between treatments (Figs. 1, 2 and 3). An increase in the proportion of low-vigor plants resulted in a decrease in plant height, greater susceptibility to lodging due to a smaller stalk diameter, and a lower number of ramifications per plant. Furthermore, the number of seeds per plant also decreased as a consequence of a lower number of pods per plant, thereby reducing the weight of seeds per plant. The only yield component assessed for which no difference was observed between plants of high and low vigor was thousand seed weight, with values statistically similar both between plants and treatments. Mondo et al. (2012) reported that the use of batches of corn seeds of varying physiological quality resulted in increased intraspecific competition. Due to the lower competitive ability of the plants arising from low-vigor seeds, the latter were dominated by those grown from highvigor seeds, as reflected in their reduced seed production. Considering the above findings, it is clear that high-vigor plants have a greater ability to establish themselves under field conditions. In the present study this characteristic resulted in their higher productivity in all treatments due to the better development of their yield components in comparison to that of the low-vigor plants.

\section{Morphological and seed yield characteristics of plant communities}

With an increase in the proportion of high-vigor plants in the population, the yield of seeds per area exhibited a linear rise (Fig. 4-d). Whereas the population formed only by low-vigor plants had a yield of $3319 \mathrm{~kg} \mathrm{ha}^{-1}$, that formed only by high- vigor plants was $4319 \mathrm{~kg} \mathrm{ha}^{-1}$, an increase of $928 \mathrm{~kg} \mathrm{ha}^{-1}$ or $21 \%$. A rise in the number of pods containing two or three seeds resulted in a similar linear increase of $19 \%$ in the number of seeds per plant (Fig. 4-a), from populations with a lower to a higher proportion of high-vigor plants in the crop row. Although the average thousand seed weight (Fig. 4-c) increased linearly by only $5 \%$ from treatment T7 (100\% LV) to treatment $\mathrm{T} 1(100 \% \mathrm{HV})$, the total weight of seeds per plant (Fig. 4-b) increased by $21 \%$.

This increase in plant yield is likely related to the homogeneity of the populations constituted only by highvigor specimens (Schuch et al., 2009; Scheeren et al., 2010; Rigo et al., 2018), as these plants exhibit better mobilization and utilization of cotyledon reserve compounds (Corte et al., 2006; Carvalho et al., 2017) for both emergence (Mielezrski and Marcos Filho, 2012; Szareski et al., 2016; Ferrari et al., 2016) and initial growth of seedlings. Therefore, the use of high-vigor seeds is essential for obtaining high yields (Mondo et al., 2012).

In the present study, the number and weight of seeds per plant had the greatest impact on the increase in seed yield per area for the populations studied. Egli (1993) evaluated the effect of soybean vigor for seeds sown in an alternating pattern along the crop row. The latter author observed that more vigorous seedlings were able to gain a competitive advantage over later-emerging plants, resulting in a $9 \%$ increase in seed yield. Similarly, Schereen (2002) reported that plants arising from high quality soybean seeds exhibited better initial height and seed yield, while Cervieri Filho (2005) found that isolated soybean plants grown from seeds of high physiological quality outperformed those grown from low quality seeds, in terms of both number of pods per plant and seed yield. A close relationship between seed vigor and yield was also observed by França Neto et al. (1984), who reported an increase of $20 \%$ to $35 \%$ in grain yield from highvigor seeds.

\section{Materials and methods}

\section{Location, soil characteristics, fertilization and genotype}

The experiment was conducted under field conditions during the 2012/2013 crop year in Selbach County, Rio Grande do Sul State - Brazil, at a site located at $28^{\circ} 39^{\prime}$ South and $53^{\circ} 01^{\prime}$ West, at $380 \mathrm{~m}$ a.s.l.

The regional soil is classified as a Dystrophic Red Typical Oxisol, based on the Brazilian Soil Classification System, Embrapa (2006). Soil analysis revealed the following properties: $\mathrm{pH}$ in water, $6.1 ; \mathrm{Ca}, 7.1 ; \mathrm{Mg}, 2.4 ; \mathrm{Al}^{3+}, 0.2 \mathrm{cmol}_{\mathrm{c}}$ $\mathrm{dm}^{-3} ; \mathrm{H}+\mathrm{Al}, 3.1$; effective $\mathrm{CTC}, 10.6 ; \mathrm{AL}^{+3}$ saturation, $2 \%$ and bases, 77\%; SMP index, 6.3; organic matter level, $2.9 \%$; clay level, 46\%; texture, 2; P-Mehlich, $12.9 \mathrm{mg} \mathrm{dm}^{-3}$; CTC $\mathrm{pH} 7$, $13.5 \mathrm{cmol}_{\mathrm{c}} \mathrm{dm}^{-3}$ and $\mathrm{K}, 333 \mathrm{mg} \mathrm{dm}^{-3}$.

Fertilizer application was performed at time of sowing in the form of $300 \mathrm{~kg} \mathrm{ha}^{-1}$ of NPK 02-20-20 fertilizer, based on soil analysis and recommendations made by the Brazilian Commission of Fertilizing and Chemistry of Soil (Cqfs-RS/SC 2004).

The soybean seeds selected for use in the study were of the cultivar FPS Urano RR, short-cycle; the seeds were also of 
certified commercial quality in order to accurately represent actual field conditions and outcomes experienced by farmers. Before sowing, all seeds were coated with fungicides ( $30 \mathrm{~g}$ active ingredient carbendazim $+70 \mathrm{~g}$ active ingredient tiram) and insecticides (150 $\mathrm{g} \mathrm{L}^{-1}$ imidacloprid + $450 \mathrm{~g} \mathrm{~L}^{-1}$ tiodicarbe), at doses of $200 \mathrm{~mL}$ and $300 \mathrm{~mL}$ commercial product per $100 \mathrm{~kg}$ of seeds, respectively.

\section{Experimental Design}

The experiment was conducted using a completely randomized design comprising seven treatments and five replications. Treatments consisted of seven combinations of seeds of high and low vigor in the sowing line, classified as follows: T1- all twelve seedlings with high vigor (100\% HV); T2- ten high-vigor seedlings and two low-vigor seedlings (83.3\% HV and $16.7 \%$ LV); T3- eight high-vigor seedlings and four low-vigor seedlings ( $66.6 \% \mathrm{HV}$ and $33.3 \% \mathrm{LV}$ ); T4- six high-vigor seedlings and six low-vigor seedlings ( $50 \% \mathrm{HV}$ and $50 \%$ LV); T5- four high-vigor seedlings and eight low-vigor seedlings (33.3\% HV and $66.6 \% \mathrm{LV}$ ); T6- two high-vigor seedlings and ten low-vigor seedlings (16.7\% HV and $83.3 \%$ LV); and T7- all twelve seedlings with low vigor (100\% LV), where HV and LV indicate high and low vigor, respectively.

In order to carry out the selection of seedlings originating from seeds of high and low vigor, a height criterion was used in which seedlings of 12 to $14 \mathrm{~cm}$ in height (from the ground to the higher end of the last trefoil leaf) were considered high-vigor seedlings, and those eight to ten $\mathrm{cm}$ in height (from the ground to the higher end of the last trefoil leaf) as low-vigor seedlings.

Sowing took place on November 30,2012 , using a no till seeder set to distribute 30 seeds per meter, at $3.0 \mathrm{~cm}$ depth and a distance of $0.45 \mathrm{~m}$ between crop rows. This high seeding rate enabled the selection, 21 days after sowing (DAS), of seedlings of high and low vigor based on the aforementioned height criterion. In this way, rows one meter in length containing 12 seedlings of interest were selected based on the treatment groups outlined above (266 thousand plants $\mathrm{ha}^{-1}$ ).

Low-vigor seedlings were duly tagged with the aid of Kraft plastic tape, attached at the base of the hypocotyl. It is important to stress that in order to avoid competition, not only were seedlings equally spaced along the crop row, but were also roughed in lateral rows, thereby achieving twelve seedlings per meter in both directions.

The control of major weeds, pests and diseases found in soybeans was performed according to the technical recommendations of Embrapa (2012).

\section{Plant evaluation and seed yield}

In each plot (crop row) the following determinations were performed: height of plant at the V5 and R8 phenological stages (Fehr and Caviness, 1997); stalk diameter; number of ramifications per plant; and the yield components number of pods with, one, two and three seeds; number of seeds per plant; seed weight per plant; thousand seed weight; and yield of seeds per area.
Plants at the V5 stage of development were measured in terms of height only. At the R8 stage of development, plants arising from seeds of high and low vigor were harvested separately to determine the remaining yield components listed above, as well as plant height. Stalk diameter was measured at ground level using a caliper rule. The number of ramifications per plant was obtained by counting ramifications on the major stem. Number of pods with one, two and three seeds, and total seeds per plant were determined via simple counting. Seed weight per plant was determined with the aid of a precision scale to two decimal places.

Thousand seed weight was determined by weighing the seeds produced by each plant of high and low vigor, and corrected to that for one thousand seeds. The overall performance of thousand seed weight was obtained per arithmetic mean for all plants of high and low vigor, in each treatment. The seed yield per area was determined based on the weight of seeds produced by each plant in each repetition, and multiplying this figure by the population of plants present (266 thousand $\mathrm{ha}^{-1}$ ), producing a final estimate of yield per hectare.

All assessments based on seed weight had their values corrected to the weight of seeds containing $13 \%$ moisture.

\section{Statistical analysis}

Experimental data were subjected to analysis of variance, with the behavior of individual plants (high and low vigor) assessed by grouping averages via the Scott-Knott (Scott and Knott 1974) test at 5\% significance, and community performance analyzed via polynomial regression.

\section{Conclusions}

Plants of high and low vigor did not differ in terms of thousand seed weight and number of pods with one seed. High-vigor seeds produced plants with greater height, stalk diameter, number of ramifications per plant, as well as a greater seed weight compared with that of low-vigor plants. The seed yield per area of the population consisting only of high-vigor plants was $21 \%\left(928 \mathrm{~kg} \mathrm{ha}^{-1}\right)$ higher than that consisting only of low-vigor plants.

\section{References}

Aisenberg GR, Koch F, Pimentel JR, Troyjack C, Dubal ITP, Santos LA, Demari GH, Szareski VJ, Villela FA, Martinazzo EG, Pedo T, Aumonde TZ (2018) Soybean growth, solar energy conversion and seed vigour affected by different nitrogen (N) doses. Aust J Crop Sci. 12: 343-349.

Carvalho IR, Nardino M, Demari GH, Szareski VJ, Follmann DN, Pelegrin AJ, Ferrari M, Olivoto T, Barbosa MH, Oliveira AC, Maia LC, Souza VQ (2017) Relations among phenotypic traits of soybean pods and growth habit. African Journal of Agricultural Research. 12: 450-458.

Carvalho NM, Toledo FF (1978) Relationships between available space for plant development and seed vigour in peanut (Arachis hypogea) plant performance. Seed Science and Technology. (6): 907-910. 
Cervieri Filho E (2005) Acting of Plants Originating from of Seeds of High and Low Energy in Population of Soybeans. Thesis (Doctorate in Science and Technology of Seeds) College of Agronomy, Federal University of Pelotas, Pelotas, 42p.

Commission of fertilizing and chemistry of soil (RS/SC) [Cqfs] (2004) Manual of Fertilization and Liming for the States of Rio Grande do Sul and Santa Catarina. 10.ed. Porto Alegre: Brazilian Society of Soil Science/Regional Center South. 400p.

Conab. National Supply Company. Ministry of Agriculture, Livestock and Food Supply (2018) Crops: Monitoring of the Brazilian crop, Eleventh survey. Available in: <http://www.conab.gov.br>. Accessed on: august 18, 2018.

Corte VB, Borges EEL, Pontes CA, Leite ITA, Ventrella MC, Mathias AA (2006) Mobilization of reserves during seed germination and growth of Caesalpinia peltophoroides Benth. (Leguminosae-Caesalpinoideae). Tree Magazine. (30): 941-949.

Edje OT, Burris JS (1971) Effects of soybean seed vigor on field performance. Agron J. 63(4): 536-538.

Egli DB (1993) Relatonship of uniformity of soybean seedling emergence to yield. Journal of Seed Technology. 17(1): 2228.

Empresa Brasileira de Pesquisa Agropecuária (Embrapa) (2006) Brazilian system of soil classification, 2nd edn. Rio de Janeiro: EMBRAPA-SPI, $306 \mathrm{p}$.

Empresa Brasileira de Pesquisa Agropecuária (Embrapa) (2012) Brazilian Company of Agricultural Research. Embrapa Wheat. Technical Indications for the Culture of Soybean in Rio Grande do Sul and Santa Catarina, Crops of 2012/2013 e 2013/2014. Embrapa Wheat, 39a Soybean Research Meeting of the Southern Region, 142p.

Fehr WR, Caviness CE (1977) Stages on soybean development. lowa State University/Cooperative Extention Service, Ames. 11p.

Ferrari M, Pelegrin, AJ, Nardino M, Carvalho IR, Szareski VJ, Olivoto T, Belle R, Oliveira AC, Maia LC, Souza VQ (2016) Evaluation of soybeans genotypes in field environments of Rio Grande do Sul state, Brazil. International Journal of Current Research. 8: 38383-38392.

França Neto JB, Henning AA (1984) Physiological quality of seeds. Londrina: Embrapa Cnpso. 5-24p.

Gabriel M, Muraro DS, Rosa GM, Wastowski AD, Kulczynski SM, Silva JC, Carvalho IR, Szareski VJ, Stumm JO (2018) Chemical Control of Asian Soybean Rust and Its Effect in the Yield and Quality of Soybean Seeds. Journal of Agricultural Science. 10: 518-526.

Henning FA, Mertz LM, Junior EAJ, Machado RD, Fiss G, Zimmer PD (2010) Chemical composition and mobilization of reserves in high and low-effect soybean seeds. Bragantia. 69(3): 727-734.

Höfs A (2003) Vigor of rice seeds and crop performance. Thesis (Doctorate in Science and Technology of Seeds) College of Agronomy, Federal University of Pelotas, Pelotas, 44p.

Khah EM, Roberts EH, Ellis RH (1989) Effects on seed ageing on growth and yield of spring wheat at different plantpopulation densities. Field Crops Res. (20) 175-190.
Kolchinski EM (2003) Seed vigor and intraspecific competition in soybeans. Thesis (Doctorate in Science and Technology of Seeds) - College of Agronomy, Federal University of Pelotas, Pelotas. 44p.

Kolchinski EM, Schuch LOB, Peske ST (2005) Seed vigor and intraspecific competition in soybeans. Cienc Rural. 35(6): 1248-1256.

Kolchinski EM, Schuch LOB, Peske ST (2006) Initial growth of soybeans in relation to the seeds vigor. Revista Brasileira de Agrociência. (12): 163-166.

Machado RF (2002) Performance of oat (Avena sativa L.) in relation with vigor seeds and population of plants. Pelotas. Dissertation (Master in Science and Technology of Seeds) College of Agronomy, Federal University of Pelotas, Pelotas. $46 \mathrm{p}$

Marcos Filho J (2002) Testing the seeds vigor. Seed News Pelotas. (2): 12-13.

Marcos Filho J (2015) Physiology of seeds of cultivated plants. 2. ed. Abrates, Londrina. 660p.

Melo PTBS, Schuch LOB, Assis FN, Concenço G (2006) Individual behaviour of plants arising from seeds of differents levels of physiological quality in irrigated rice. Brazilian Journal of Seeds. 28(2): 84-94.

Mielezrski F, Filho JM (2012) Physiological potential of stored seeds and performance of pea plants. Brazilian Journal of Seeds. 34(4): $665-677$.

Mielezrski F, Schuch LOB, Peske ST, Panozzo LE, Carvalho RR, Zuchi J (2008) Performance in field of isolated hybrid rice plants in relation of physiologic quality of the seeds. Brazilian Journal of Seeds. (30): 139-144.

Mondo VHV, Cicero SM, Dourado-Neto D, Pupim TL, Dias MAN (2012) Vigor seeds and performance of corn plants. Brazilian Journal of Seeds. 34(1): $143-155$.

Peske ST, Villela FA, Meneghello GE (2012) Seeds: scientific and technological foundations. Universidade Federal de Pelotas, Pelotas. 573p.

Pinthus MJ, Kimel U (1979) Speed of germination as a criterion of seed vigor in soybeans. Crop Sci. (19): 291-292.

Popinigis $F(1973)$ Effects of the physiological quality of seed on field performance of soybeans (Glycine Max (L.) Merrill) as affected by population density. (PhD Thesis). Mississippi State University, Mississippi, 85p.

Popinigis, F (1977) Physiologic of seeds. Brasília, DF, AGIPLAN.

Rigo GA, Schuch LOB, Barros WS, Vargas RL, Szareski VJ, Carvalho IR, Pimentel JR, Troyjack C, Jaques LA, Rosa TC, Souza VQ, Aumonde TZ, Pedo T (2018) Effects of Macronutrients in the Physiological Quality of Soybean Seeds. Journal of Agricultural Science. 10: 312-318.

Rigo GA, Scuch LOB, Vargas RL, Barros WS, Szareski VJ. Carvalho IR, Troyjack C, Pimentel JR, Escalera RAV, Da Rosa TC, Souza VQ, Aumonde TZ, Pedo T (2018) Micronutrient Content and Physiological Quality of Soybean Seeds. Journal of Agricultural Science. 10: 223-230.

Scheeren BR, Peske ST, Schuch LOB, Barros ACSA (2010) Physiological quality and yield of soybean seeds. Brazilian Journal of Seeds. (32): 35-41.

Scheeren BV (2002) Soybean vigor seed and productivity. Thesis (Doctorate in Science and Technology of Seeds) - 
College of Agronomy, Federal University of Pelotas, Pelotas, 45p.

Schuch, LOB (1999) Seed vigor and aspects of crop physiology in oats (Avena strigosa Screb). Pelotas. Thesis (Doctorate in Science and Technology of Seeds) - College of Agronomy, Federal University of Pelotas, Pelotas, 127p.

Schuch LOB, Kolchinski EM, Finatto JA (2009) Seed quality and performance of individual plants in soybean. Brazilian Journal of Seeds. 31(1): 144-149.

Schuch LOB, Nedel JL, Assis FN, Maia MS (2000) Field emergence and initial growth of black oats in response of the vigor seed. Brazilian Journal of Agrociência. Pelotas. 6(2): 97-101.

Scott AJ, Knott MA (1974) Cluster Analysis Method for Grouping Means in the Analysis of Variance. Biometrics. 30(3): 507-512.

Szareski VJ, Carvalho IR, Nardino M, Demari G, Bahry CA, Kehl K, Pedo T, Zimmer PD, Souza VQ, Aumonde TZ (2016) Phenotype stability of soybean genotypes for characters related to the physiological quality of seeds produced under different environmentall conditions. Australian Journal of Basic and Applied Sciences. 10(15): 279-289.

Szareski VJ, Carvalho IR, Demari GH, Souza VQ, Rosa TC, Villela FA, Pedo T, Aumonde TZ (2018) Multivariate index of soybean seed vigor: a new biometric approach applied to the effects of genotypes and environments. Journal of Seed Science. 40 (4): 396-406.

Szareski VJ, Carvalho IR, Kehl K, Levien AM, Nardino M, Dellagostin SM, Demari GH, Lautenchleger F, Villela FA, Pedo T, Souza VQ, Aumonde TZ (2018) Evaluation of the adaptability and stability of wheat genotypes using a phenotypic index of seed vigor. Pesquisa Agropecuária Brasileira. 53(6): 727-735.
Szareski VJ, Carvalho IR, Demari GH, Pelissari G, Pelegrin AJ, Barbosa MH, Rosa TC, Santos NL, Martins TS, Nardino M, Pedo T, Souza VQ, Aumonde TZ (2018) Path analysis applied to agronomic traits of contrasting growth habit soybeans. Australian Journal of Crop Science. 12(4): 531538.

Tavares LC, Rufino CA, Tunes LM, Barros ACSA (2013) Yield and quality of soybean seeds of high and low vigor subjected to water stress. Interciência. 38(1): 73-80.

Tekrony DM, Egli DB (1991) Relationship of seed vigor to crop yeild: a review. Crop Sci. (31): 816-822.

Vanzolini S, Carvalho NM (2002) Effect of soybean seed vigor on their performance on field. Brazilian Journal of Seeds. 24(1): 33-41.

Vargas RL, Schuch LOB, Barros WS, Rigo GA, Szareski VJ, Carvalho, IR, Pimentel JR, Troyjack C, Souza VQ, Rosa TC, Aumonde TZ, Pedo T (2018) Macronutrients and Micronutrients Variability in Soybean Seeds. Journal of Agricultural Science. 10: 209-222.

Villiers TA (1973) Ageing and longevity of seeds in field conditions. In: Heydecker, W (ed). Seed ecology. Pennsylvania State University Press, London. 265-288p.

Zanatta E, Szareski VJ, Carvalho IR, Pimentel JR, Troyjack C, Dellagostin SM, Demari G, Lautenchleger F, Souza VQ, Martinazzo EG, Villela FA, Aumonde TZ (2018) Pre-harvest Desiccation: Productivity and Physical and Physiological Inferences on Soybean Seeds During Storage. Journal of Agricultural Science. 10: 354-362.

Zimmer G, Koch F, Carvalho IR, Szareski VJ, Demari GH, Nardino M, Follmann DN, Souza VQ, Aumonde TZ, Pedo T (2016) Seed quality and initial performance os seedlings of soybean produced off-season in Rio Grande do Sul, Brasil. International Journal of Current Research. 8: 40325-40329. 